\title{
Meningkatkan Pengetahuan Masyarakat Dalam Menjaga Imunitas Dengan Obat Tradisional di Era Normal Baru
}

\author{
Neny Purwitasari ${ }^{1^{*}}$, Mangestuti Agil ${ }^{2}$, Ema Qurnianingsih ${ }^{3}$ \\ 1, 2 Departemen Ilmu Kefarmasian, Fakultas Farmasi, Universitas Airlangga \\ 3 Departemen Ilmu Biokimia Kedokteran, Fakultas Kedokteran, Universitas Airlangga \\ ${ }^{1 *}$ neny-p@ff.unair.ac.id, ${ }^{2}$ mangestuti@ff.unair.ac.id, ${ }^{3}$ ema-q@fk.unair.ac.id
}

\begin{abstract}
Abstrak
Pandemi Covid-19 yang melanda dunia sejak akhir tahun 2019 telah menimbulkan keresahan dan kerugian yang tinggi bagi masyarakat dunia termasuk Indonesia. Vaksin dan obat yang sampai saat ini belum tersedia secara luas membuat masyarakat harus menjaga daya tahan tubuh atau imunitas dengan baik. Salah satu cara menjaga imunitas adalah dengan mengkonsumsi obat tradisional secara tepat. Obat tradisional menjadi alternatif yang baik untuk menjaga imunitas karena khasiatnya telah terbukti secara turun-temurun, dan mempunyai efek samping minimal apabila digunakan secara tepat. Maka dari itu, kegiatan ini bertujuan untuk memberi pengetahuan kepada mayarakat dalam meningkatkan kekebalan tubuh dengan mengkonsumsi jamu secara tepat. Kegiatan dilaksanakan dengan media poster dan modul yang diberikan kepada kelompok masyarakat yang masih berkegiatan di luar rumah selama masa normal baru dan memiliki kesempatan berinteraksi dengan orang lain seperti tukang parkir, pedagang keliling dan pedagang warung nasi di wilayah Surabaya Timur. Setelah mendapat penyuluhan dengan menggunakan media tersebut, sebanyak 30 responden kegiatan ini mendapat peningkatan pengetahuan mengenai jenis obat tradisional, cara pembuatan dan cara mengkonsumsinya untuk meningkatkan imunitas. Kesimpulan kegiatan ini, masyarakat mendapat pengetahuan dan dapat mengaplikasikan pengetahuan mengenai obat tradisional untuk menjaga imunitas untuk diri sendiri dan keluarga. Metode pemberian materi melalui poster dan brosur dapat diterima dengan baik dan memotivasi untuk menjaga imunitas dengan obat tradisional di era normal baru.
\end{abstract}

Kata Kunci: imunitas, obat tradisional, normal baru

\section{Pendahuluan}

Pada akhir tahun 2019, dunia dikejutkan dengan mewabahnya virus Corona jenis baru dari Wuhan yang telah di konfirmasi oleh WHO. Kasus yang terus meningkat bahkan di Indonesia per tanggal 26 Desember 2020 kasus di Indonesia adalah sebanyak 706.837 (https://infeksiemerging.kemkes.go.id/).

Semenjak pemberlakuan era normal baru beberapa bulan lalu oleh Presiden RI, kini masyarakat Indonesia sudah mulai berangsur-angsur melakukan berbagai kegiatan normal di luar rumah. Era normal baru merupakan masa transisi untuk hidup normal secara berdampingan dengan keberadaan virus Corona yang masih ada di sekitar kita. 
Maka dari itu salah satu cara menjaga agar tidak tertular adalah dengan menjaga imunitas perorangan dengan mengkonsumsi obat tradisional. Menurut Badan Pengawas Obat dan Makanan, obat tradisional adalah bahan atau ramuan bahan yangberupa bahan tumbuhan, bahan hewan, bahan mineral, sediaan sarian (galenik) atau campuran dari bahan tersebut yang secara turun temurun telah digunakan untukpengobatan, dan dapat diterapkan sesuai dengan norma yang berlaku di masyarakat (BPOM, 2020a).

Beberapa obat tradisional yang secara empiris telah lama digunakan oleh masyarakat bahkan telah mendapat bukti secara ilmiah digunakan sebagai imunomodulator. Obat tradisional dimanfaatkan dan dinyatakan aman, dapat dimanfaatkan dengan kriteria bahwa tumbuhan obat tersebut didukung oleh data ilmiah yang mendukung (BPOM, 2020a). Menurut BPOM tahun 2020 diantara obat tradisional yang telah terbukti secara empiris dan didukung oleh penelitian ilmiah memiliki khasiat memelihara kesehatan adalah:

1. Herba Sambiloto dengan nama latin Andrographis paniculata (Burm. f), memiliki bahan aktif Andrografolida yang telah terbukti secara klinis memiliki khasiat untuk meringankan gejala ISPA dan memiliki khasiat sebagai imunomodulator. Cara penggunaanya adalah dengan menggunakan herba kering sebanyak 3-9g, atau herba segar sebanyak 25-75 gr sebagai dosis tunggal sesuai kebutuhan.

2. Herba Meniran dengan nama latin Phyllanthus niruri $L$ memiliki bahan aktif tanin, damar, kalium, flavonoid yang memiliki kasiat secara ilmiah sebagai imunomodulator dan imunostimulan juga sebagai antivius. Cara penggunaannya adalah herba segarsebanyak 15-30 gr dikonsumsi sebanyak 2-3kali sehari.

3. Rimpang Kunyit dengan nama latin Curcuma longa L memiliki kandungan utama kurkumin memiliki banyak manfaat sebagai antiradang dan imunomodulatr dengan cara penggunaan sebanyak 2-4 gr serbuk kering.

4. Rimpang Temulawak dengan nama latin Curcurma xanthorrhiza Roxb. Memiliki kandungan kurkuminoid dan minyak atsiri yang memiliki khasiat secara ilmiah sebagai imunomodulator dan antiradang. Penggunaanya adalah irisan rimpang segar sebanyak 25 gr per hari.

5. Rimpang Jahe dengan nama latin Zingiber officinale Roscoe memiliki kandungan utama minyak atisiri yang memiliki khasiat sebagai imunostimulan dan antiradang. Penggunaannya adalah serbuk kering 2-4 gr perhari

6. Buah dan daun Jambu Biji dengan nama latin Psidium guajava memiliki kandungan utama vitamin $C$ dan kuersetin memiliki khasiat secara ilmiah sebagai antiradang, antioksidan adan antivirus. Cara menggunakannya adalah dengan mengkonsumsi satu buah segar ukuran sedang setiap hari atau dengan mengkonsumsi 15 gr daun segar per hari.

Cara pengolahan secara umum adalah untuk bahan simplisia kering atau segar direbus dengan $250 \mathrm{ml}$ air selama 15 menit apabila bahan lunak dan 30 menit apabila bahan keras. Bahan yang berupa serbuk dapat diseduh dengan $150 \mathrm{ml}$ air matang panas (BPOM, 2020b).

Ramuan ini perlu disosialisasikan kepada masyarakat untuk menjaga daya tahan tubuh dalam menghadapi era normal baru dimana kasus positif Covid 19 juga masih 
tinggi di Indonesia. Kelompok masyarakat yang dipilih adalah masyarakat dengan mobilitas tinggi dan memiliki akses yang kurang optimal terhadap informasi pencegahan covid 19. Kementrian Sosial menyarankan untuk memasang poster pesan kunci penting langkah-langkah untuk pencegahan Covid 19 (www.puspensos.kemsos.go.id). Menurut Kementrian Komunikasi dan Informasi, pemerataan informasi sangat penting untuk keberhasilan penanganan bencana Covid 19. Penggunaan media baik itu online maupun konvensional juga sangat penting dalam penyampaian informasi baik berupa himbauan maupun sosialisasi langkah-langkah penting agar dipatuhi oleh masyarakat (https://kominfo.slemankab.go.id/pemerataan-akses-informasi-salah-satu-unsur-

penting-penanganan-covid-19/). Maka dari itu, langkah-langkah pencegahan dengan mengkonsumsi jamu perlu dimasyarakatkan. Poster adalah salah satu media yang tepat di masa pandemi karena poster dapat memuat langkah-langkah kunci yang penting, informasinya padat dan lebih mudah dipahami.

\section{Metode Pelaksanaan}

Kondisi pandemi membatasi kegiatan yang bersifat mengumpulkan masa. Maka dari itu, kegiatan ini tetap mematuhi protokol kesehatan yang ditetapkan oleh pemerintah. Kegiatan ini dilaksanakan dengan media poster dan modul mengenai manfaat jamu dengan bahan-bahan yang tlah di anjurkan oleh BPOM dan sekaligus langkah-langkah pembuatan jamu kepada kelompok masyarakat. Sedangkan masyarakat sasaran adalah yang masih berkegiatan di luar dan sering berkumpul dengan khalayak ramai misalnya penjaga parkir, penjaga warung makan, warung kopi dan pedagang keliling di sekitar wilayah Surabaya Timur pada tanggal 27 Juli 2020 - 03 Agustus 2020. Kurangnya kesadaran untuk melakukan protokol kesehatan juga menyebabkan kelompok masyarakat ini rentan tertular penyebaran virus Covid-19 dan bahkan bisa menjadi pembawa penyebaran virus kepada keluarga. Maka dari itu, kegiatan ini menyasar kelompok masyarakat tersebut.

Kegiatan ini bekerjasama dengan Badan Eksekutif Mahasiswa Fakultas Farmasi Universitas Airlangga divisi Pengabdian Kepada Masyarakat. Poster dan modul yang berisi materi mengenai pola hidup normal baru, jenis-jenis bahan jamu yang berkhasiat untuk menjaga imunitas sekaligus cara pembuatan secara sederhana, dibagikan dan dijelaskan oleh pelaksana kegitan dengan protokol kesehatan yang ketat seperti selalu menggunakan masker dan face shield, menghindari berkerumun dan selalu menjaga kebersihan dengan mencuci tangan menggunakan sabun atau Hand Sanitizer sebelum dan sesudah melaksanakan kegiatan. Peningkatan pengetahuan dievaluasi dengan pre dan post test. Indikator keberhasilan kegiatan ini adalah adanya peningkatan pengetahuan masyarakat mengenai pola hidup normal baru sekaligus cara meningkatkan imunitas dengan mengkonsumsi jamu, baik untuk diri sendiri maupun keluarga. Selain itu, adanya evaluasi kegiatan juga dijadikan sebagai indikator keberhasilan kegiatan ini. Salah satu poster berisi panduan menjaga imunitas dengan obat tradisional di masa normal baru terlampir pada gambar 1 dan 2. Sedangkan fotofoto kegiatan penyuluhan terdapat pada gambar 3 . 


\section{Madaniya \\ ISSN 2721-4834}

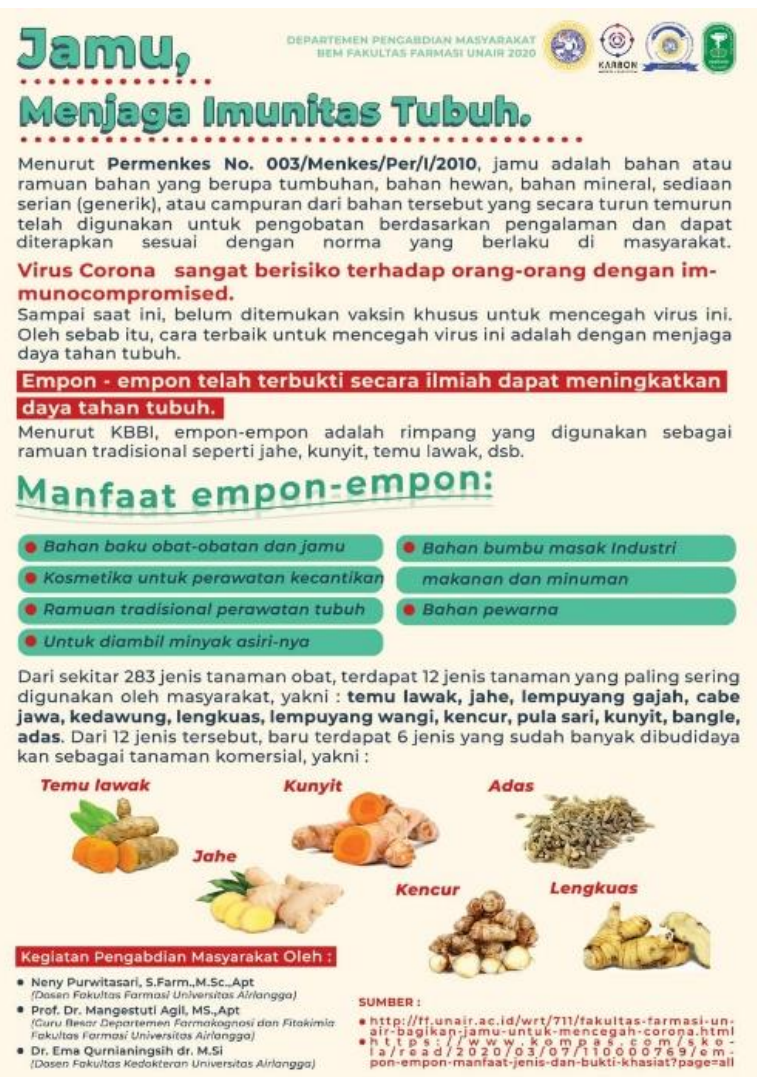

Gambar 1. Poster mengenai penjelasan bahan jamu yang dapat digunakan untuk menjaga imunitas.

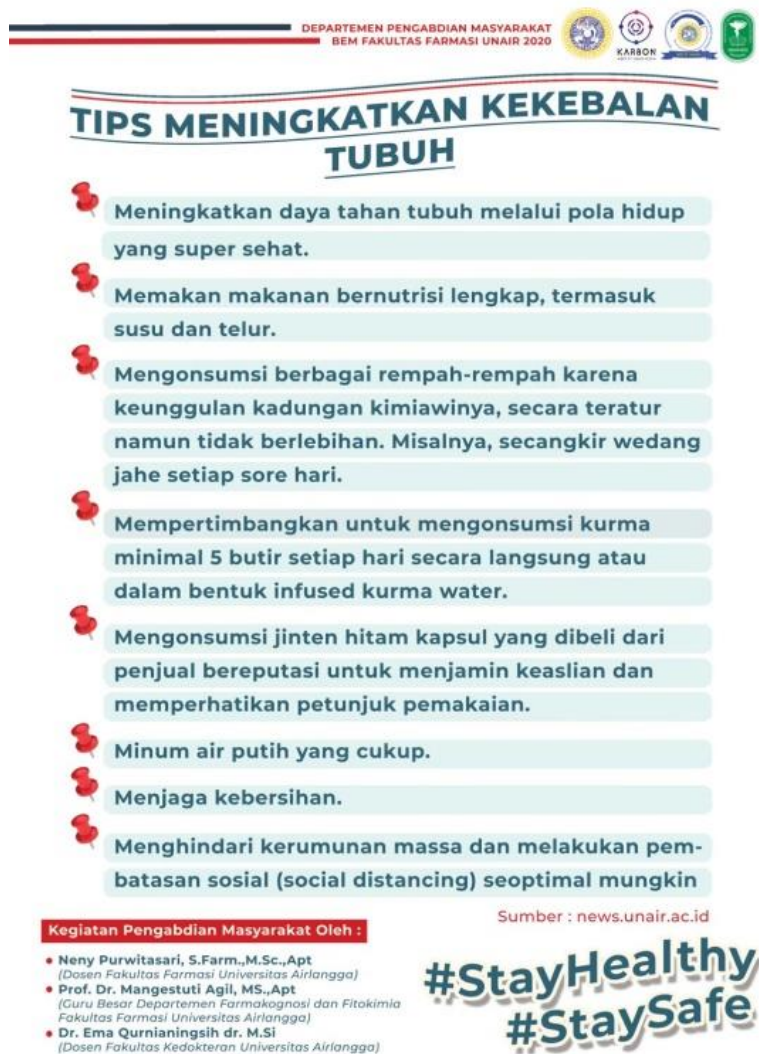

Gambar 2. Poster mengenai cara meningkatkan kekebalan tubuh di masa normal baru 
Vol. 2, No. 1, Februari 2021

ISSN 2721-4834

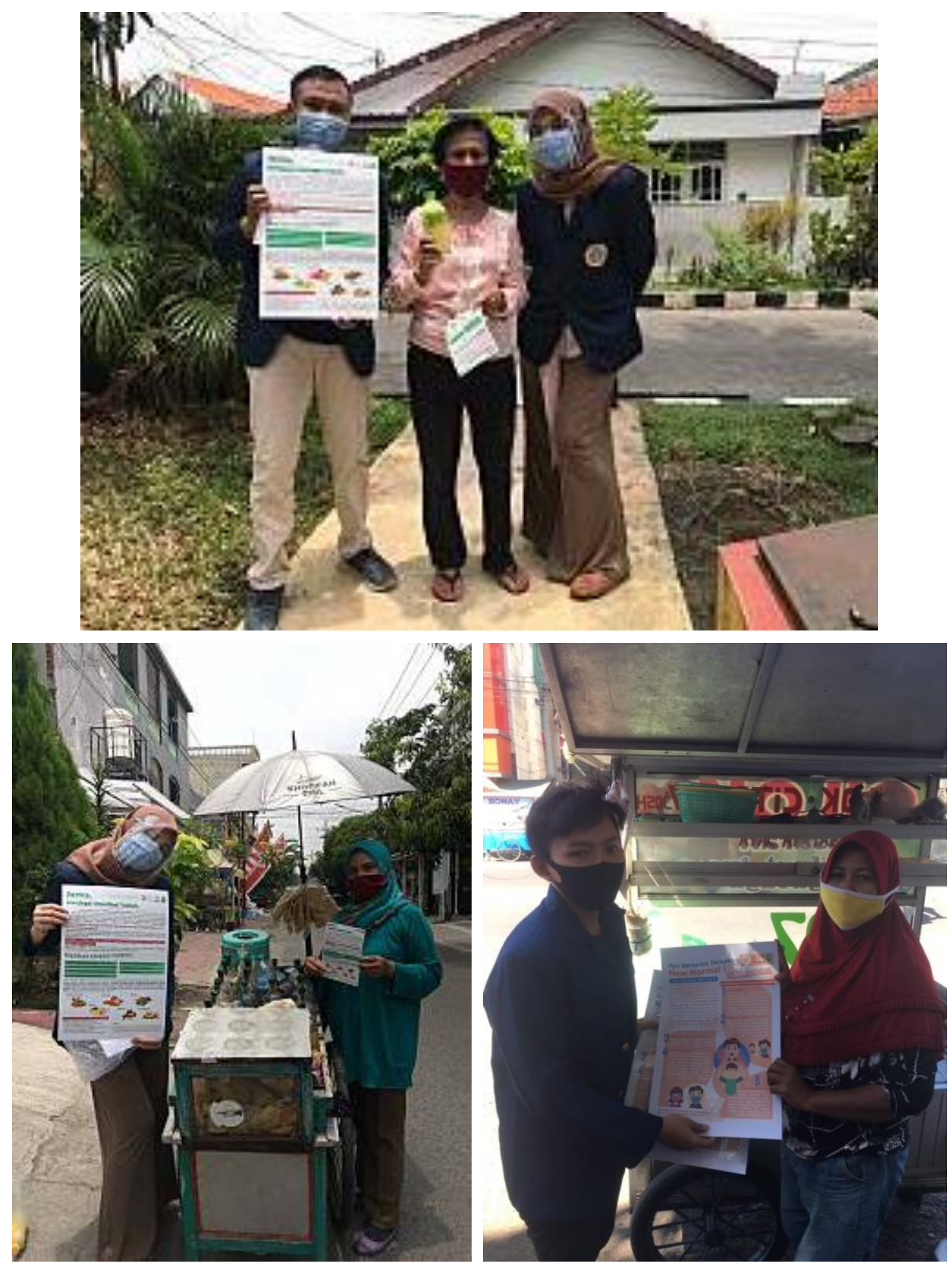

Gambar 3. Penyuluhan melalui media poster \& modul dilakukan sesuai protokol kesehatan

\section{Hasil dan Pembahasan}

Untuk mengukur pengetahuan mengenai materi maka sebelum dan sesudah kegitan penyuluhan, responden mengisi pre test dan post test pengetahuan mengenai bahan jamu dan cara pengolahannya. Hasilnya tercantum pada tabel 1. 
Tabel 1. Hasil Pre dan Post test

\begin{tabular}{lll}
\hline Pertanyaan & $\begin{array}{l}\text { Menjawab benar } \\
\text { pada Pre test (\%) }\end{array}$ & $\begin{array}{l}\text { Menjawab benar } \\
\text { pada Post test (\%) }\end{array}$ \\
\hline $\begin{array}{l}\text { Apakah obat bisa } \\
\text { meningkatkan daya } \\
\text { tahan tubuh? }\end{array}$ & 83,33 & 100 \\
$\begin{array}{l}\text { Apakah jamu bisa } \\
\text { mengobati penyakit }\end{array}$ & 40 & \\
$\begin{array}{l}\text { Covid? } \\
\begin{array}{l}\text { Apakah kunyit dan } \\
\text { jahe yang sudah } \\
\text { berjamur dan rusak } \\
\text { boleh digunakan? }\end{array}\end{array}$ & 80 & \\
$\begin{array}{l}\text { Untuk mendapatkan } \\
\text { manfaatnya apakah } \\
\text { minum jamu harus } \\
\text { rutin? }\end{array}$ & 40 & 100 \\
$\begin{array}{l}\text { Apakah bahan- } \\
\text { bahan yang keras } \\
\text { seperti akar dan } \\
\text { rimpang harus } \\
\text { direbus lebih lama? }\end{array}$ & 50 & 76,67 \\
\hline $\begin{array}{l}\text { PERSENTASE } \\
\text { RATA-RATA }\end{array}$ & 58,66 & \\
\hline
\end{tabular}

\section{Evaluasi Kegiatan}

Kegiatan penyuluhan melalui media poster dan modul dipilih karena di masa pandemi kegiatan berkumpul untuk memberikan penyuluhan lebih dari 10 orang adalah sangat dibatasi. Poster dan modul diberikan secara individu kepada responden diikuti dengan penjelasan singkat mengenai materi. Responden diberi kesempatan untuk membaca dan memahami isi materi sebelum mengisi post test dan evaluasi kegiatan. Kegiatan ini juga memiliki kelemahan yaitu waktu yang dibutuhkan lebih lama karena harus mendatangi responden secara individu.

Hal hal yang di evaluasi adalah keefektifan media poster dan modul dalam menyampaikan materi, apakah isi pada media mudah dipahami, apakah materi yang diberikan bermanfaat bagi masyarakat serta apakah materi dapat memotivasi untuk menjaga imunitas dengan obat tradisional dijelaskan dengan digram pada gambar 5, 6, 7, dan 8. 
Vol. 2, No. 1, Februari 2021

ISSN 2721-4834

Poster dan Modul sebagai Media Penyampaian Materi Dinilai Efektif (\%)

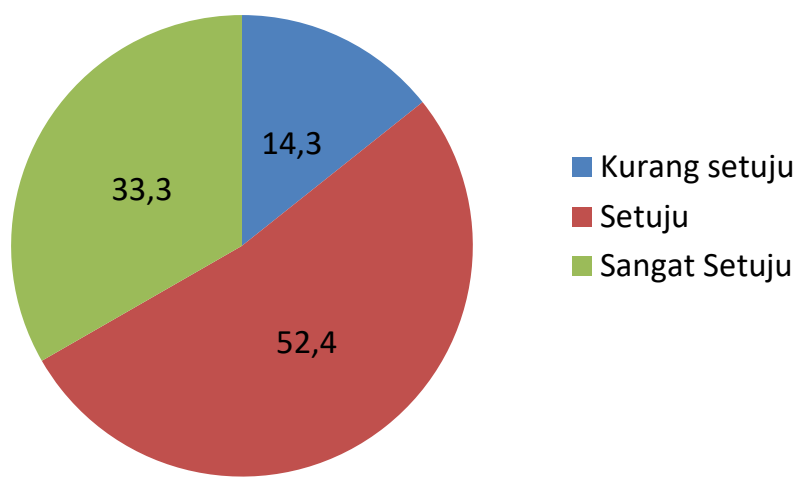

Gambar 5. Hasil evaluasi Poster dan Modul sebagai Media Penyampaian Materi dinilai Efektif

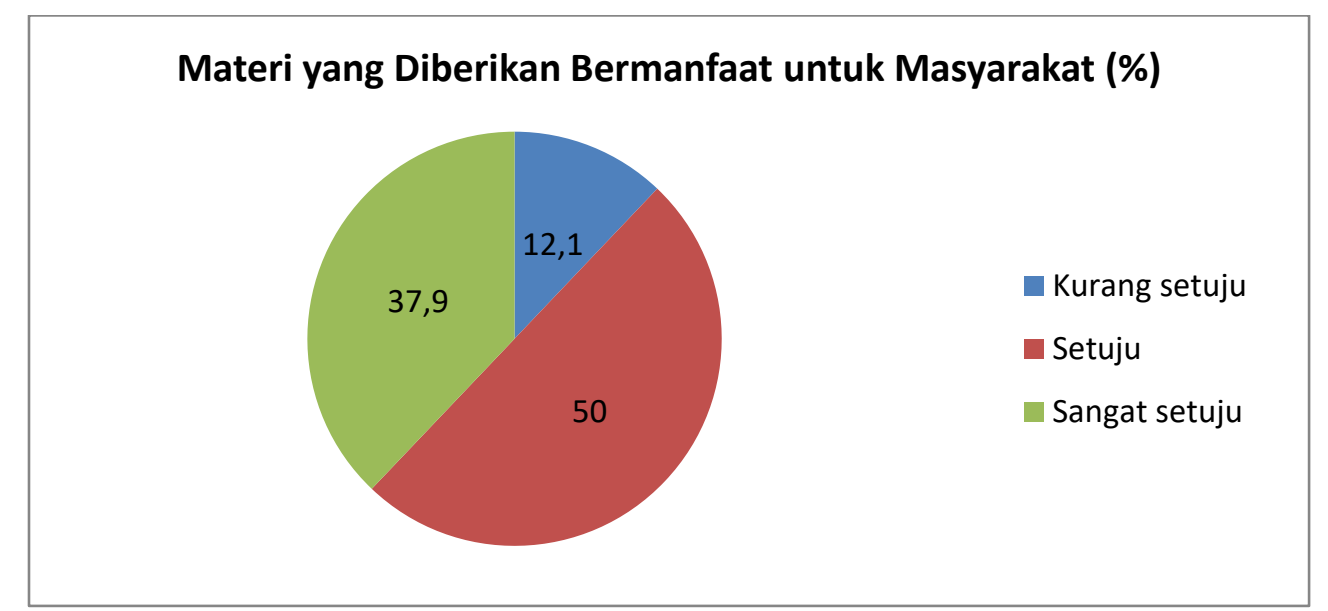

Gambar 6. Hasil evaluasi mengenai materi yang diberikan bermanfaat bagi masyarakat

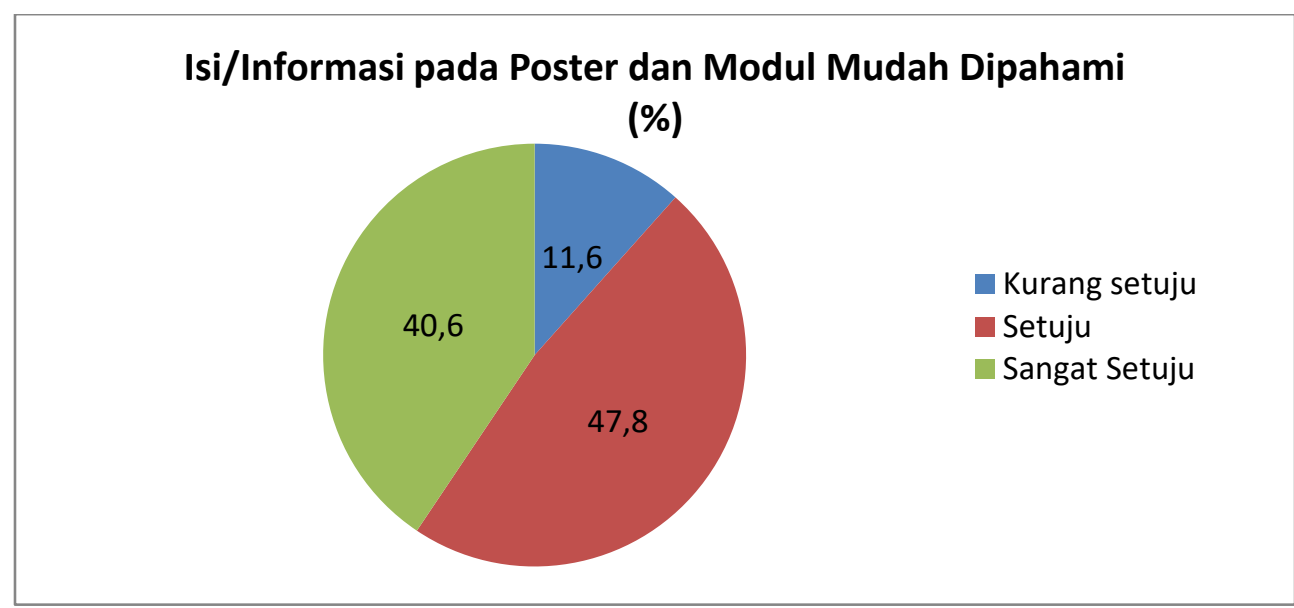

Gambar 7. Hasil evaluasi mengenai isi/informasi pada poster dan modul mudah dipahami 


\section{Poster dan Modul dapat Memotivasi untuk Meningkatkan Imunitas dengan Obat Tradisional (\%)}

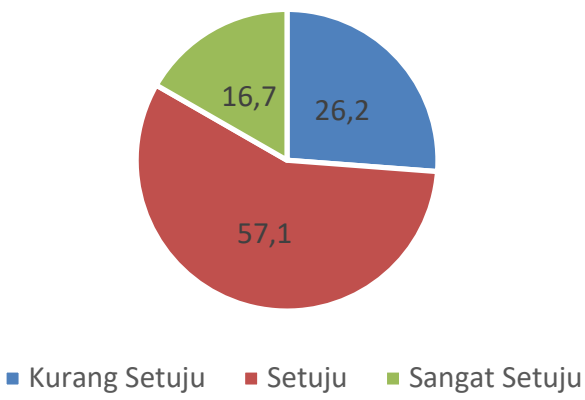

Gambar 8. Hasil evaluasi mengenai poster \& modul dapat memotivasi untuk meningkatkan imunitas dengan Obat Tradisional

Masa normal baru yang telah diterapkan di Indonesia sejak beberapa bulan lalu membuat masyarakat sudah mulai baraktivitas secara normal di luar rumah dengan tetap melaksanakan protokol kesehatan yaitu memakai masker, menjaga jarak dan menghindari kerumunan. Akan tetapi, terkadang masyarakat lalai dalam menjaga protokol kesehatan sehingga kasus Covid 19 di Indonesia belum menunjukkan angka penurunan sampai tanggal 25 Desember 2020 ini. Belum tersedianya vaksin dan obat antivirus secara luas, membuat masyarakat harus tetap menjaga kekebalan tubuh dengan mengkonsumsi makanan bergizi, rutin berolah raga dan mengkonsumsi jamu secara rutin. Jamu adalah obat asli Indnesia yang teah terbukti secara turun temurun dapat membantu mengatasi masalah kesehatan. Kandungan jamu yang mudah di peroleh, mudah dijangkau dengan harga yang tidak terlalu mahal juga menjadi alternatif pilihan yang baik bagi masyarakat di tengah meroketnya harga vitamin bahkan ketersediaanya mulai langka di apotek.

Kelompok masyarakat sasaran adalah yang masih berkegiatan di luar rumah dengan potensi berkumpul dan berkerumun sangat tinggi seperti tukang parkir, pedagang keliling maupun penjaga warung makan dan warung kopi. Kelompok masyarakat ini juga memiliki mobilitas tinggi dan interaksinya dengan orang lain sangat tinggi sehingga rawan terpapar virus Corona.

Dari post test terlihat adanya peningkatan minat dan pengetahuan responden terhadap obat tradisional yang digunakan untuk menjaga kekebalan tubuh dari 58,66 persen sebelum kegiatan menjadi 90 persen setelah kegiatan. Sebanyak $52,4 \%$ responden mengaku sangat setuju bahwa poster dan modul sebagai media penyampaian materi dinilai efektif. Sebanyak 50\% responden berpendapat sangat setuju bahwa materi yang diberikan bermanfaat bagi masyarakat. Hanya 11,6 \% respnden merasa tidak setuju mengenai informasi pada poster dan modul mudah dipahami, sisanya sebanyak 40,6 \% merasa setuju dan 47,8 \% merasa sangat setuju. Sedangkan sebanyak 57,1 responden berpendapat sangat setuju dan $16,7 \%$ setuju apabila mereka lebih termotivasi untuk meningkatkan imunitas dengan obat tradisional. 


\section{Kesimpulan}

Kesimpulan kegiatan ini adalah adanya peningkatan pengetahuan masyarakat mengenai jenis-jenis bahan obat tradisional yang digunakan untuk menjaga imunitas dan cara mengolahnya maupun cara mengkonsumsinya. Mayoritas masyarakat paham dengan materi yang disampaiakan dengan media poster dan modul dan semakin meningkatkan motivasi untuk menjaga imunitas selama era normal baru dengan menerapkan pola hidup sehat dan mengkonsumsi obat tradisional. Pemakaian media ini cukup efektif.

\section{Ucapan Terimakasih}

Kegiatan Pengabdian Kepada Masyarakat ini dibiayai oleh Lembaga Penelitian dan Inovasi Universitas Airlangga dengan skema Hibah Riset Mandat Khusus Covid-19 Universitas Airlangga tahun 2020 dengan nomor kontrak 1081/UN.314/PT/2020.

\section{Referensi}

Badan Pengawas Obat dan Makanan. (2020). Pedoman Penggunaan Herbal dan Suplemen Kesehatan dalam Menghadapi COVID-19 di Indonesia. Jakarta: Badan Pengawas Obat dan Makanan

Badan Pengawas Obat dan Makanan. (2020). Buku Saku Obat Tradisional Untuk Memelihara Daya Tahan Tubuh. Badan Pengawas Obat dan Makanan

https://puspensos.kemsos.go.id/peran-penting-penyuluh-sosial-masyarakatmenghadapi-pandemi-covid-19 diakses tanggal 24 Desember 2020.

https://kominfo.slemankab.go.id/pemerataan-akses-informasi-salah-satu-unsurpenting-penanganan-covid-19/ diakses tanggal 24 Desember 2020.

https://infeksiemerging.kemkes.go.id/ diakses tanggal 26 Desember 2020. 